\title{
Investigasi Perilaku Spontan Individu Saat Bencana Alam: Dalam dan Luar Bangunan
}

\section{Investigation of Spontaneous Behavior of Individuals During Natural Disasters: Inside and Outside Buildings}

\section{Ulfa Mazaya}

Program Studi Magister Arsitektur, SAPPK, Institut Teknologi Bandung, Bandung, Indonesia umazaya@yahoo.com

\section{Marlisa Rahmi,}

Program Studi Magister Arsitektur, SAPPK, Institut Teknologi Bandung, Bandung, Indonesia marlisa.rahmi@gmail.com

\section{Hanson E Kusuma}

Kelompok Keahlian Perancangan Arsitektur, SAPPK, Institut Teknologi Bandung, Bandung, Indonesia hangsong@ar.itb.ac.id

\begin{abstract}
Abstrak
Indonesia merupakan negara yang rawan terhadap bencana alam, baik bencana yang dapat terjadi secara tiba-tiba maupun perlahan. Bencana alam yang terjadi dapat memberikan dampak kejutan akibat kurangnya kewaspadaan dan persiapan dalam menghadapi ancaman. Salah satu respons yang terlihat dari dampak yang ditimbulkan oleh bencana tersebut adalah pada pola perilaku manusia. Perilaku manusia sangat sulit untuk diprediksi saat berada di keadaan darurat yang menegangkan dan kacau balau tersebut. Perilaku spontan yang terjadi dipengaruhi faktor lokasi keberadaan, yaitu saat berada di dalam bangunan seperti dalam bangunan tempat tinggal dan bangunan umum lainnya, atau di luar bangunan. Tujuan penelitian ini adalah untuk mengungkap perilaku spontan manusia yang dilakukan saat terjadi bencana alam saat berada di dalam dan luar bangunan. Penelitian ini merupakan penelitian kualitatif yang bersifat eksploratif. Data dikumpulkan menggunakan kuesioner daring dengan pertanyaan yang bersifat terbuka (open-ended) dan dibagikan secara bebas. Hasil analisis menunjukkan bahwa dalam merespons kejadian bencana alam, terdapat kecenderungan manusia untuk tetap bertahan saat berada di bangunan umum dan memilih untuk menjauhi bangunan saat berada di tempat tinggal. Sedangkan individu yang sedang berada di luar bangunan, mereka akan cenderung memilih untuk tidak bertindak sama sekali.
\end{abstract}

Kata kunci: bencana alam, perilaku manusia, perilaku spontan

\begin{abstract}
Indonesia is prone to natural disasters that can occur unexpectedly and gradually. Natural disasters implement surprising impacts due to a lack of awareness and preparedness in facing the threats. One of the reasons caused by such a disaster that can be seen is through human behavior. Human behavior is challenging to predict in an emergency, stressful and chaotic. Spontaneous behavior is distinguished by location factors, indoor or outdoor, with indoor, divided by Home and Public Building. This research aims to reveal spontaneous human behavior during natural disasters while inside and outside the building. This research was conducted with a qualitative exploratory method. Data were collected using an online questionnaire with open-ended questions and distributed freely. The findings show tendencies to withstand when in the public building while going to distance themselves from building while at home, as for those outdoor opt to surrender as not to do anything
\end{abstract}


Keywords:: natural disaster, human behavior, spontaneous behavior

Received: 2020-11-30 | Accepted: 2021-02-12 | DOI: 10.29080/eija.v6i2.1084| Page: 119-129

EMARA: Indonesian Journal of Architecture http://jurnalsaintek.uinsby.ac.id/index.php/EIJA

This article is open access distributed under the terms of the Creative Commons Attribution ShareAlike 4.0 International License, which permits unrestricted use, distribution, and reproduction in any medium provided the original work is properly cited.

\section{Pendahuluan}

Berdasarkan data yang dikeluarkan oleh Badan Perserikatan Bangsa-Bangsa untuk Strategi Internasional Pengurangan Risiko Bencana (UN-ISDR), Indonesia merupakan negara yang paling rawan terhadap bencana di dunia. Setiap tahun, terdapat beberapa jenis bencana alam yang terjadi di Indonesia seperti angin puting beliung, tanah longsor, banjir, gempa bumi dan tsunami. Bencana-bencana tersebut dapat terjadi secara tiba-tiba maupun berlangsung perlahan dan terprediksi secara berkala. Ketidakpastian bencana alam tersebut akan memberikan dampak kejutan diakibatkan kurangnya kewaspadaan dan persiapan dalam menghadapi ancaman yang ditimbulkan.

Perilaku individu dapat dipengaruhi oleh lingkungan fisik, dimana desain arsitektur berperan sebagai lingkungan fisik. Manusia banyak menghabiskan kehidupan sehari-hari di lingkungan fisik. Perilaku manusia dipengaruhi oleh pola pikir yang telah terbentuk sesuai dengan lingkungan fisik yang mereka tempati. Lingkungan fisik tersebut dapat berupa bangunan hunian, kantor, sekolah, hingga bagian di luar bangunan (Benthorn \& Frantzich, 1999; Sagun et al., 2013)

Manusia sangat bergantung pada pengalaman pribadi yang pernah dilalui dalam mengambil suatu keputusan. Namun, perilaku manusia sulit untuk di prediksi, dan menjadi lebih sulit lagi saat berada di situasi darurat yang menegangkan dan kacau, seperti bencana alam. Perilaku yang terjadi berbeda saat berada di dalam keadaan darurat yang baru, unik dan berbeda dengan keadaan hariannya (Ursano et al., 1995).

Manusia hidup dalam lingkungan fisik, dimana lingkungan tersebut mempengaruhi perilaku yang muncul. Lingkungan menentukan tingkah laku (Environmemntal Determinism), dan juga lingkungan dapat memberikan kesempatan atau hambatan terhadap tingkah laku (Enviromental Posibilism), (Haryadi, 2010; Rapoport, 2016).

Pada penelitian yang dilakukan terkait gempa bumi di Jepang, ditemukan bahwa pola perilaku yang terjadi saat gempa terpengaruhi keadaan lingkungan fisik. Faktor dari gempa bumi saja dianggap tidak cukup untuk melihat penyebab perilaku yang terbentuk. Faktor lingkungan fisik seperti jenis bangunan, luas, dan sebagainya menjadi suatu pertimbangan tersendiri (Ohta \& Ohashi, 1985). Dapat dilihat bahwa bangunan sebagai lingkungan fisik, dalam menghadapi gempa bumi, memiliki peran dalam menentukan perilaku yang terjadi (Environmental Determinism).

Lingkungan fisik juga dapat memberikan kesempatan atau hambatan terhadap suatu perilaku untuk terjadi (Environmental Posibilism). Pada penelitian yang dilakukan terkait Great Japan Earthquake (Yun \& Hamada, 2012), data yang diambil menunjukkan bahwa $48 \%$ dari yang tidak selamat tidak melakukan evakuasi atau tidak dapat melakukan evakuasi. Pada penelitian 
lainnya (Archea \& Kobayashi, 1983), ditemukan bahwa penghuni harus melindungi diri dari objek yang berjatuhan dikarenakan kurangnya faktor nonstruktural, seperti perabot, yang dapat digunakan sebagai untuk berlindung. Faktor tersebut menjadi penghambat untuk melakukan suatu tindakan menyelamatkan diri.

Penelitian yang telah dilakukan di Indonesia terkait perilaku saat bencana, seperti gempa bumi, sejauh ini hanya membahas pengaruh kesiapsiagaan saja (Fahrevy et al., 2014; Firmansyah, 2014; Kurniawati \& Suwito, 2017). Penelitian tersebut kebanyakan berasal dari segi studi kebencanaan tanpa ada kaitan lebih dalam mengenai perilaku tepat saat terjadi bencana.

Penelitian lain yang kerap dilakukan adalah mempelajari perilaku manusia pada bencana alam secara tradisional (Okabe \& Hirose, 1985), walaupun minat penelitian ini lebih ke mengarah ke level perilaku spontan. Analisis yang banyak dilakukan sering berkaitan dengan keadaan sebelum atau sesudah bencana alam, sementara kajian akan perilaku manusia tepat di saat terjadinya bencana alam masih sangat terbatas. Pengamatan terhadap perilaku spontan tepat pada saat bencana ini memungkinkan identifikasi perilaku spontan keselamatan yang diambil di saat darurat.

Untuk mengindetifikasi perilaku spontan saat terjadi bencana, survei lebih baik dilakukan tepat setelah responden mengalami kejadian terkait bencana alam dengan keadaan ingatan akan bencana belum memudar. Tetapi, survei juga dapat dilakukan dengan menggali ulang (recall) memori pengalaman bencana.

Penelitian ini bertujuan untuk mempelajari perilaku spontan saat keadaan darurat bencana pada lingkungan fisik di dalam bangunan dan di luar bangunan. Penelitian ini dilakukan untuk mengungkap perilaku yang muncul saat menghadapi gempa bumi pada bangunan dan luar bangunan pada pengalaman terdahulu Pengetahuan yang diungkap dapat memberkan rekomendasi dan pertimbangan desain bagi arsitek dalam menciptakan bangunan hunian dengan pertimbangan perilaku penghuni saat gempa bumi.

\section{Metode}

Penelitian ini merupakan penelitian kualitatif yang bersifat eksploratif. Penelitian kualitatif eksploratif bertujuan untuk mendapatkan data berupa informasi mengenai perilaku spontan yang dilakukan saat bencana alam dan lokasi serta jenis bencana yang dialami dari para responden. Pengumpulan data dilakukan dengan menyebarkan kuesioner daring dengan pertanyaan yang bersifat terbuka (open-ended) yang dibagikan secara bebas (non-random sampling) (Kumar, 2018). Kuesioner dibagikan pada tanggal 1 September 2019. Responden diminta untuk menuliskan selengkap mungkin perilaku spontan yang diambil beserta perasaan dan pikiran mereka saat menghadapi bencana alam. Jumlah responden yang diperoleh sebanyak 134 orang. Sebanyak 96 responden $(71,6 \%)$ pernah mengalami bencana alam dan 38 responden $(28,3 \%)$ belum pernah mengalami bencana alam (Gambar 1).

Wilayah penelitian ini dibatasi pada wilayah Indonesia, dengan alasan pemilihan dikarenakan, mengutip data dari Badan Nasional Penanggulangan Bencana (BNPB), Indonesia merupakan salah satu negara dengan tingkat gempa yang tinggi di dunia. Walaupun yang dikaji adalah seluruh Indonesia, namun dalam pelaksanaan lebih difokuskan kepada kota yang pernah mengalami bencana skala sedang hingga besar. Adapun responden 
yang dipilih sebagai subjek penelitian difokuskan kepada masyarakat yang pernah mengalami bencana saat berada pada bangunan dan luar bangunan di Indonesia. Jenis bencana merupakan bencana yang kerap terjadi di Indonesia, seperti angin puting beliung, tanah longsor, banjir, gempa bumi dan tsunami. Bencana-bencana tersebut terjadi secara tiba-tiba dan tidak terprediksi, karena perilaku yang ingin diteliti adalah yang terjadi secara spontan.

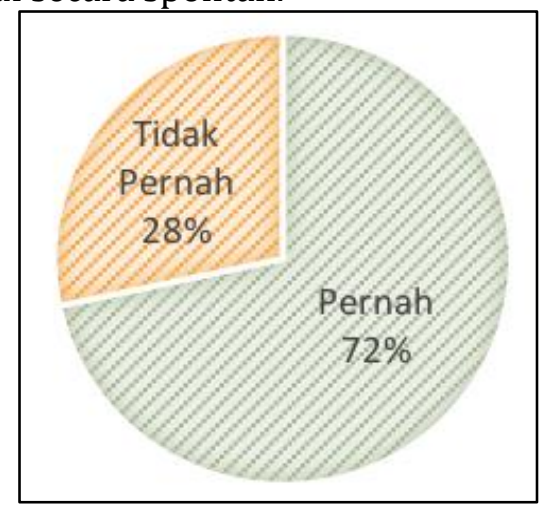

Gambar 1. Histogram Pengalaman Responden (Sumber:peneliti, 2019)

Data yang diperoleh dianalisis dengan metode analisis isi yang dilakukan melalui tiga tahapan yaitu open coding, axial coding dan selective coding (Creswell, 2013). Pada tahapan open coding, dilakukan identifikasi segmen makna, kode, dan kategori dari jawaban yang diberikan responden. Selanjutnya pada tahap axial coding, dilakukan analisis korespondensi antar kategori. Tahap akhir adalah selective coding yang berupa penyusunan model hipotesis berdasarkan hasil analisis hubungan antar kategori yang didapat dalam tahap axial coding.

\section{Result and Discussions Latar belakang reponden}

Dari hasil analisis, ditemukan responden terbagi menjadi dua kategori, yaitu yang pernah mengalami bencana alam sebanyak 96 orang dan yang tidak pernah mengalami sebanyak 38 orang. Kota tempat responden mengalami bencana alam berasal dari 11 kota di Indonesia (Gambar2), yaitu: Aceh (34\%), Bali (3\%), Banten (6\%), DI Yogyakarta (11\%), DKI Jakarta (14\%), Jawa Barat (7\%), Jawa Tengah (6\%), Jawa Timur (10\%), Sulawesi Tengah (3\%), Sumatera Barat (1\%), dan Sumatera Utara (5\%).Menurut data UNISDR (United Nations Office for Disaster Risk Reduction) bahwa resiko bencana di Indonesia sangat tinggi. Data survei yang dilakukan PBB memaparkan bahwa untuk potensi Tsunami, Indonesia menempati peringkat pertama dari 265 negara di dunia.

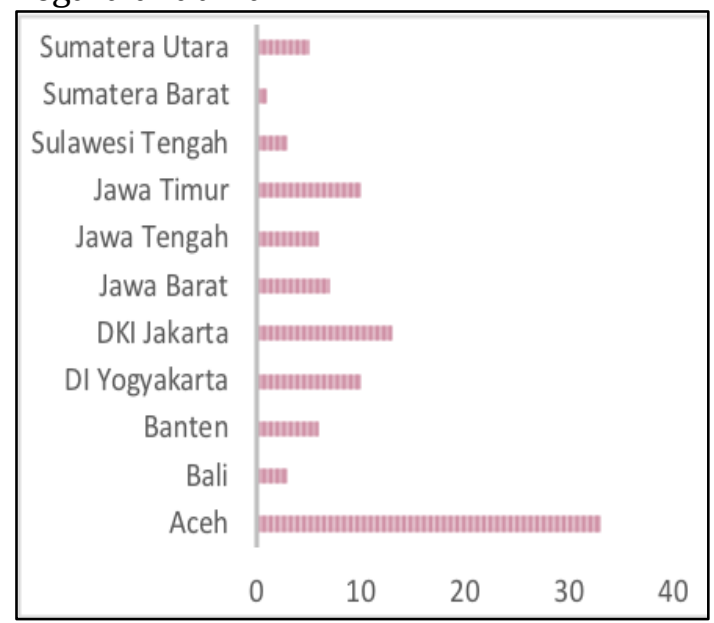

Gambar 2. Frekuensi kota lokasi bencana responden (Sumber: Analisis, 2019).

Hasil analisis korespondensi antara jenis bencana alam dengan kota tempat tinggal responden diperlihatkan pada dendogram gambar 3 ( $p$ value = $<0,0001)$. Dendogram tersebut menunjukkan tingkat kebetulan (korespondensi/coincidence) antara jenis bencana dan kota. Tsunami cenderung terjadi di Aceh. Letusan gunung api dan gempa bumi terjadi di Bali, Jawa Barat, Yogyakarta, dan Jawa Tengah, serta Banten, Sumatera Utara, dan Sulawesi Utara. Banjir cenderung terjadi di Jakarta dan Jawa Timur. Tanah longsor cenderung terjadi di Sumatera 


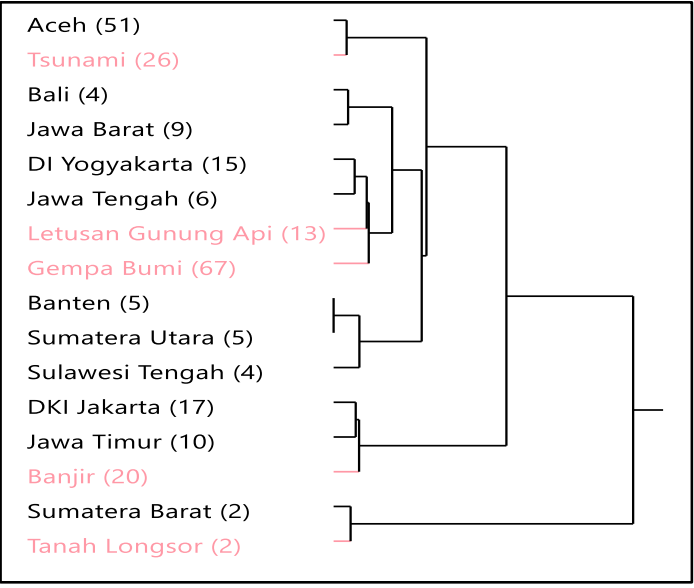

Gambar 3. Dendogram korespondensi antara kota lokasi bencana dengan jenis bencana alam (Sumber: Analisis, 2019)

\section{Perilaku spontan saat bencana}

Data teks tentang perilaku spontan yang diambil saat bencana dianalisis dengan open coding. Tabel 1 ini menunjukkan contoh open coding.

Tabel 1. Contoh Open Coding Perilaku Spontan

\begin{tabular}{|c|c|c|}
\hline $\begin{array}{c}\text { Pertanya } \\
\text { an }\end{array}$ & Jawaban & Kode \\
\hline $\begin{array}{l}\text { Langkah } \\
\text { apa saja } \\
\text { yang } \\
\text { anda } \\
\text { lakukan } \\
\text { saat } \\
\text { terjadi }\end{array}$ & $\begin{array}{l}\text { Karena masih } \\
\text { berumur } 2 \\
\text { tahun, saya di } \\
\text { gendong keluar } \\
\text { rumah. } \\
\text { Kemudian kami } \\
\text { berkumpul di } \\
\text { tengah } \\
\text { lapangan/sawah } \\
\text { kosong yang } \\
\text { jauh dari tiang } \\
\text { listrik }\end{array}$ & $\begin{array}{l}\text {-Anak } \\
\text { bergantung } \\
\text { Pada orang } \\
\text { dewasa. } \\
\text {-Menjauhi } \\
\text { bangunan. } \\
\text {-Menuju } \\
\text { ruang } \\
\text { terbuka }\end{array}$ \\
\hline tersebut? & $\begin{array}{l}\text { Segera keluar } \\
\text { rumah dan } \\
\text { menghindari } \\
\text { bangunan atau } \\
\text { pergi ke } \\
\text { lapangan }\end{array}$ & $\begin{array}{l}\text {-Menjauhi } \\
\text { bangunan. } \\
\text {-Menuju } \\
\text { ruang } \\
\text { terbuka. }\end{array}$ \\
\hline
\end{tabular}

Sumber: analisis peneliti, (2019)

Kode yang didapat dari open coding seperti berdiam di dalam bangunan, berdoa, mencari perlindungan, menjauhi bangunan, menuju ruang terbuka, kemudian dikelompokkan ke dalam kategori-kategori tertentu yang bersifat lebih umum (Tabel 2).
Tabel 1. Contoh Open Coding Kode-Kategori Perilaku

\begin{tabular}{ll}
\hline \multicolumn{1}{c}{ Kode } & \multicolumn{1}{c}{ Kategori } \\
\hline -Menjauhi Bangunan & \\
-Menuju Ruang & Evakuasi \\
Terbuka & \\
-Menuju Lokasi Aman & \\
\hline -Mengamankan Harta & \\
Benda & \\
-Mengumpulkan & Sikap Tanggap \\
Keluarga & \\
\hline
\end{tabular}

Sumber: analisis peneliti, (2019)

Ditemukan 7 kategori perilaku spontan yang diambil pada saat terjadi bencana alam (Tabel 3). Dengan melakukan analisis distribusi, diketahui frekuensi kategori jawaban responden yang ditemukan dari yang tertinggi hingga terendah, meliputi; Evakuasi (44 \%), Sikap Tanggap (24\%), Perlindungan (16\%), Bertahan (6\%), Pasrah (5\%), Spiritual (3\%) dan Kebutuhan Khusus (2\%) (Gambar 4).

Tabel 3. Open Coding Perilaku Spontan

\begin{tabular}{ll}
\hline \multicolumn{1}{c}{ Kategori } & \multicolumn{1}{c}{ Kode } \\
\hline Evakuasi & $\begin{array}{l}\text { Menjauhi Bangunan } \\
\text { Menuju Ruang Terbuka }\end{array}$ \\
\hline Sikap Tanggap & $\begin{array}{l}\text { Menghentikan Aktifitas } \\
\text { Mengontrol Emosi }\end{array}$ \\
\hline Perlindungan & Mencari Perlindungan \\
\hline Bertahan & $\begin{array}{l}\text { Berdiam Didalam } \\
\text { Bangunan }\end{array}$ \\
\hline Pasrah & Tidak Bertindak \\
& Berdiam \\
\hline Spiritual & $\begin{array}{l}\text { Berdoa } \\
\text { Mitos }\end{array}$ \\
\hline Kebutuhan & $\begin{array}{l}\text { Anak Bergantung Pada } \\
\text { Khusus }\end{array}$ \\
\hline
\end{tabular}

Sumber: analisis peneliti, (2019)

Perilaku spontan yang merupakan kategori evakuasi meliputi menjauhi bangunan, menuju ruang terbuka hingga menuju lokasi aman. Kegiatan yang dilakukan pada kategori sikap tanggap meliputi menghentikan aktifitas, mengontrol emosi yang timbul, 
mengamankan harta benda hingga berusaha untuk menganalisis kondisi sekitar (Tabel 3).

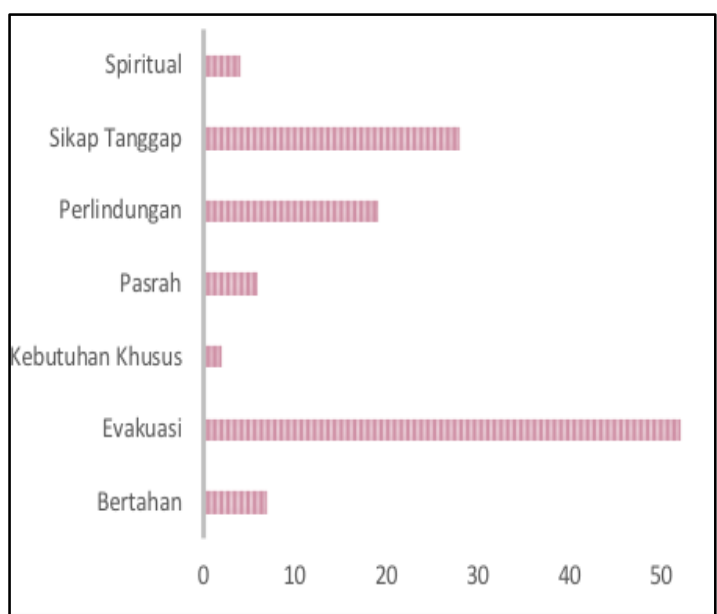

Gambar 4. Frekuensi kategori perilaku spontan saat bencana alam (Sumber: Analisis, 2019)

Kategori perlindungan muncul dari tindakan untuk mencari perlindungan. Dalam kategori bertahan, yang dilakukan responden adalah memilih untuk berdiam di dalam bangunan. Terdapat pula kategori pasrah. Pada kategori pasrah, responden tidak melakukan tindakan apapun dan memilih berdiam saja tanpa mengetahui perilaku apa yang harus dilakukan. Kategori spiritual meliputi kegiatan berdoa dan juga mempercayai mitos tertentu terkait bencana alam tertentu. Kemudian kategori kebutuhan khusus merupakan perilaku spontan yang lebih mengarah ke responden yang memiliki kebutuhan sendiri, seperti pada anak-anak yang membutuhkan bantuan orang dewasa untuk melindungi diri (Tabel 3).

\section{Perilaku Spontan Dalam dan Luar Bangunan}

Dalam kegiatan harian, manusia beraktifitas di berbagai tempat sesuai dengan kebutuhan dan prioritas tiap individu. Faktor lingkungan tempat responden berada mempengaruhi variasi perilaku spontan (Huo et al 2014).
Perilaku setiap individu akan berbeda saat berada di lingkungan keluarga dan lingkungan kerja(Murakami \& Durkin, 1988).

Pada penelitian yang dilakukan saat gempa bumi di Jepang (Ohta \& Ohashi, 1985) ditemukan bahwa keadaan lingkungan fisik memiliki peran terhadap perilaku yang terjadi. Lingkungan fisik tersebut dapat berupa bangunan, namun lingkungan di luar bangunan juga termasuk. Pada penelitian yang dilakukan (Murakami \& Durkin, 1988) menyatakan lebih banyak korban jiwa ditemukan pada bangunan, seperti bangunan hunian, sekolah dan perkantoran. Namun, penelitian tersebut dalam konteks gempa bumi. Pada penelitian lain terkait gempa bumi, yang kemudian disusul oleh bencana Tsunami (Goto, 2011; Yun \& Hamada, 2012), menunjukkan bahwa perilaku saat dan setelah gempa bumi berpengaruh pada keselamatan saat menghadapi bencana susulan Tsunami. Perilaku yang nenyebabkan korban yang tidak selamat salah satunya adalah permasalahan terkait perilaku mereka yang terhambat saat berada di lingkungan fisik di luar bangunan, yaitu di jalanan.

Dapat dilihat, bahwa perilaku yang perlu dilihat dapat dibedakan menjadi saat berada di dalam bangunan, dan di luar bangunan. Tentunya tidak terlepas dari faktor atribut responden seperti usia, jenis kelamin, dan pengalaman terdahulu beserta jenis bencana alam itu sendiri (Ohta \& Ohashi, 1985).

Oleh karena itu, untuk mengetahui perbedaan perilaku spontan saat di dalam dan luar bangunan dilakukan analisis korespondensi. Analisis ini merupakan tahap axial coding dari analisis ini. Hasil analisis korespondensi diperlihatkan pada dendrogram diagram 5 ( $p$ value $=0,0328$ ). 


\section{Perilaku Spontan Dalam Bangunan}

Identifikasi tempat seperti rumah, tempat kerja, dan tempat khusus tertentu diperlukan untuk menganalisis perilaku spontan saat bencana (Song et al., 2014). Dari hasil open coding, lingkungan dalam bangunan terbagi menjadi dua sesuai kegiatan yaitu untuk bangunan: Tempat Tinggal dan Umum.

Dari gambar 5, dapat diketahui bahwa responden yang berada di tempat tinggal saat bencana cenderung melakukan perilaku spontan evakuasi. Dalam konteks evakuasi tersebut, frekuensi kode dari perilaku evakuasi, meliputi: menjauhi bangunan (52\%), menuju lokasi yang lebih aman (20\%), menuju ruang terbuka (13\%), menjauhi lokasi bencana (4\%) serta menyelamatkan harta benda (11\%) (gambar 6). Dapat dilihat bahwa untuk bangunan tempat tinggal, perilaku spontan yang dilakukan oleh orang yang berada di sekitar area tersebut adalah cenderung menjauhi bangunan. Sebuah studi yang dilakukan oleh Fujisaki (1979) terkait gempa Miyagi (Miyagi earthquake) pada tahun 1978 menunjukkan bahwa korban bencana lebih banyak ditemukan pada bangunan tempat tinggal dari pada kantor dan sekolah (Murakami \& Durkin, 1988).

$$
\text { Pada bangunan umum, }
$$

keselamatan dari banyak orang tergantung pada perilaku yang diberikan oleh sosok tertentu seperti guru di sekolah, suster di rumah sakit, manajer di pusat perbelanjaan, dan sebagainya (Song et al., 2014). Dari hasil analisis, ditemukan bahwa responden yang berada di bangunan umum seperti sekolah, kantor, kampus, pusat perbelanjaan, dan fasilitas kesehatan, cenderung memilih untuk bertahan di dalam bangunan. Temuan ini bertolak belakang dengan perilaku spontan yang dilakukan oleh individu yang mengalami bencana ketika sedang berada di bangunan tempat tinggal.

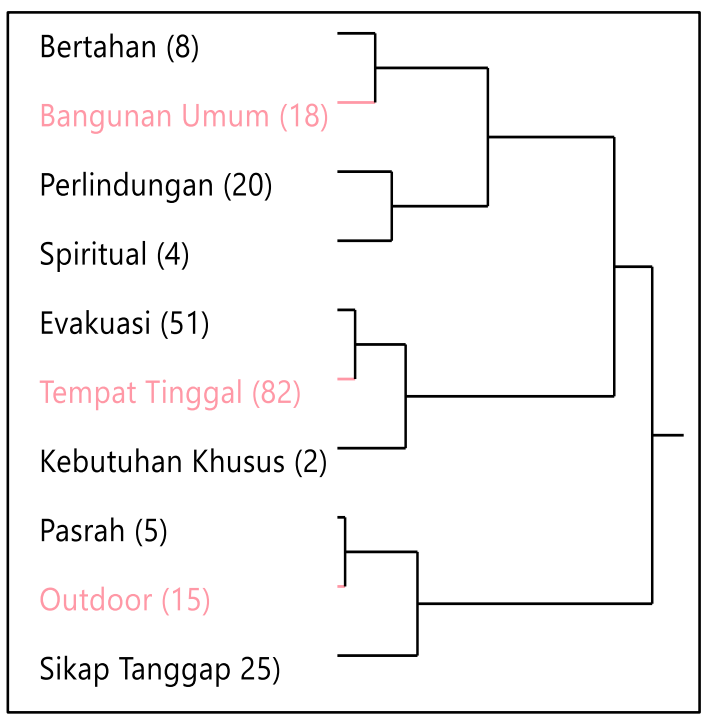

Gambar 5. Dendogram korespondensi antara lokasi dalam dan luar bangunan dengan perilaku spontan yang diambil (Sumber: Analisis, 2019)

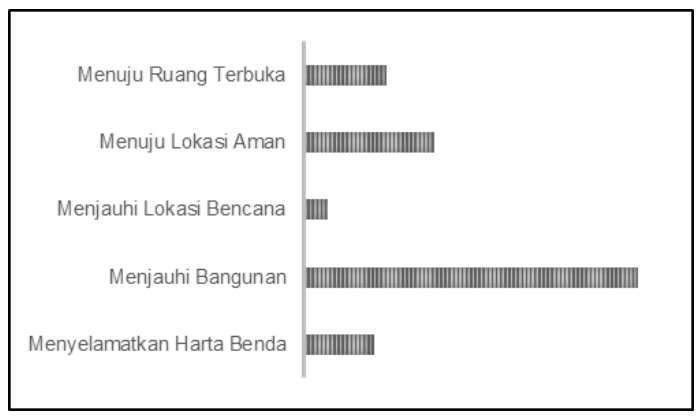

Gambar 6. Frekuensi kode dari kategori perilaku dalam bangunan (Sumber: Analisis, 2019)

\section{Perilaku Spontan Luar Bangunan}

Hasil analisis kondisi lalu lintas segera setelah gempa bumi Hanshin-Awaji (Great Hanshin earthquake) terjadi menunjukkan bahwa tidak hanya jalan utama saja yang mengalami kerusakan, tetapi juga jalanjalan kecil (Odani \& Uranaka, 1999). Dengan analisis open coding, didapat data lingkungan di luar bangunan berupa jalan (saat berkendara), lapangan, fasilitas olahraga luar bangunan, pasar, dan kebun. Hasil analisis menunjukkan bahwa pada saat berada di luar bangunan, perilaku spontan responden cenderung pasrah hingga tidak bertindak sama sekali (f: 5), 
dan sikap tanggap (f: 25) seperti yang dapat dilihat pada gambar 5 dan gambar 7 . Temuan ini berbeda dengan perilaku spontan dari responden yang berada di tempat tinggal yang salah satunya adalah mencari lingkungan luar bangunan seperti lapangan dan ruang terbuka. Perilaku spontan sikap tanggap meliputi menghentikan aktifitas dan menghentikan kendaraan.

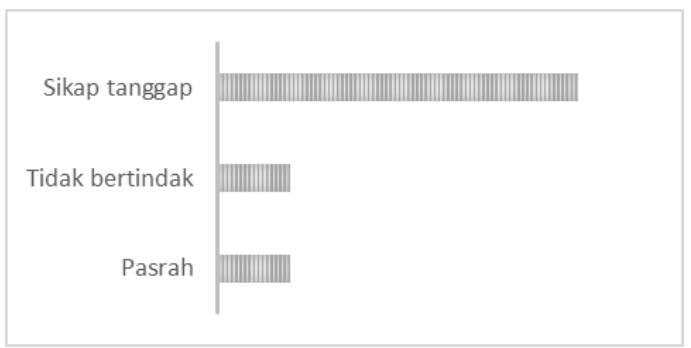

Gambar 7. Frekuensi kode dari kategori perilaku luar bangunan (Sumber: Analisis, 2019)

Berdasakan hasil analisis open coding dan axial coding, dilakukan selective coding dengan menyusun model hipotesis hubungan perilaku spontan tepat saat bencana alam terjadi pada lingkungan di dalam dan luar bangunan. Model hipotesis diperlihatkan pada gambar 8 berikut

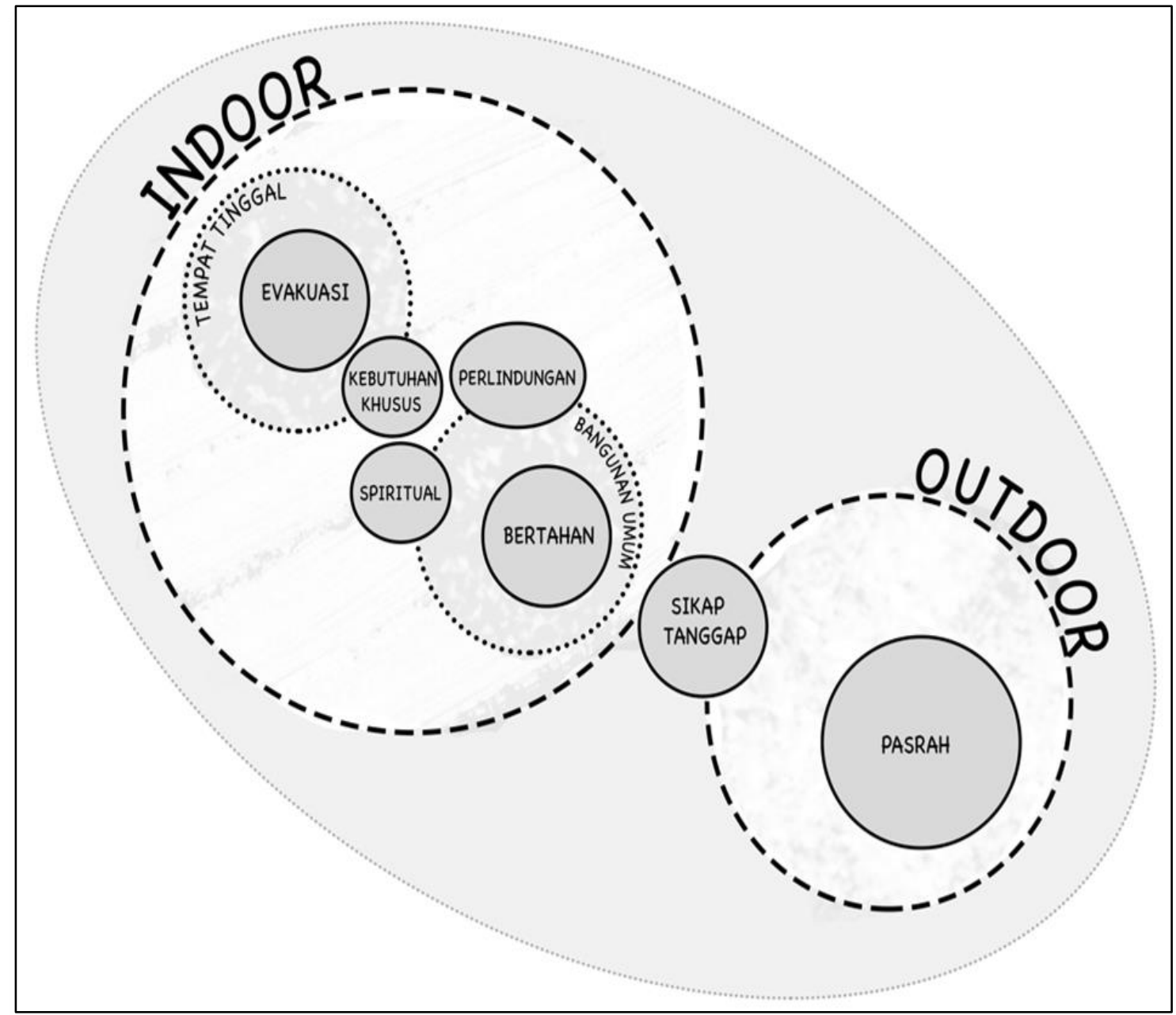

gambar 8. Hipotesis hubungan perilaku spontan lingkungan di dalam dan luar bangunan (Sumber: Analisis peneliti (2019) 


\section{Kesimpulan}

Hasil analisis perilaku spontan dikorespondensikan dengan faktor lingkungan tempat responden berada, yaitu saat mereka berada di luar bangunan dan saat di dalam bangunan. Lingkungan di dalam bangunan dibagi sesuai dengan jenis bangunan yang ditempati: tempat tinggal dan bangunan umum. Ditemukan bahwa pada bangunan tempat tinggal perilaku spontan yang cenderung dilakukan adalah evakuasi. Evakuasi dilakukan responden dengan menjauhi bangunan dan juga mencari tempat aman dan ruang terbuka. Sedangkan pada bangunan umum, yang terjadi adalah kebalikannya yaitu perilaku spontan yang dilakukan adalah bertahan di dalam bangunan. Pada lingkungan luar bangunan seperti jalan (berkendara) dan fasilitas olahraga, ditemukan perilaku spontan yang terjadi adalah pasrah dan sikap tanggap dari responden.

Penelitian ini mengungkap perilaku spontan yang muncul tepat saat keadaan darurat terjadi di bangunan rumah tinggal, bangunan umum, dan di luar bangunan. Temuan yang didapat diharapkan dapat digunakan untuk memprediksi perilaku spontan dan memberikan sudut pandang baru untuk penyusunan kebijakan mitigasi bencana. Misalnya, temuan dapat digunakan oleh arsitek dalam merancang bangunan yang aman terhadap bencana, earthquake safety planner untuk merancang protokol keselamatan saat bencana, hingga sektor pemerintah maupun non-pemerintah (NGO).

Bila ditinjau secara praktik, hasil dari penelitian ini dapat menjadi pertimbangan dalam desain, terutama bagi para arsitek yang menginginkan rancangan lingkungan fisik dengan mempertimbangan perilaku. Terutama jika lingkungan yang akan dirancang berada dalam wilayah yang rentan pada jenis bencana alam tertentu.
Penelitian ini sangat dimungkinkan untuk dilanjutkan secara kuantitatif untuk meneliti lebih lanjut kaitannya dengan atribut lingkungan fisik seperti luas bangunan, akses keluar masuk hingga keberadaan faktor struktural dan nonstruktural. Penelitian ini dapat membuka peluang untuk dilakukan penelitian sejenis dengan pertimbangan variabel yang lebih terukur.

\section{Pernyataan penulis}

Dengan ini penulis menyatakan bahwa penelitian ini terbebas dari konflik kepentingan dengan pihak manapun

\section{Ucapan terimakasih}

Penulis mengucapkan terimakasih kepada Institut Teknologi Bandung beserta semua pihak yang telah mendukung kegiatan penelitian ini

\section{Referensi}

Archea, J., \& Kobayashi, M. (1983). The Behavior of People in Dwellings During the Off-Urakawa Earthquake of 21St March 1982. Disasters, 7(4), 312-312. https://www.safetylit.org/citatio ns/index.php?fuseaction=citation s.viewdetails\&citationIds[]=citjou rnalarticle_35438_35

Benthorn, L., \& Frantzich, H. (1999). Fire alarm in a public building: How do people evaluate information and choose an evacuation exit? Fire and Materials, 23(6), 311-315. https://doi.org/10.1002/(SICI)10 991018(199911/12)23:6<311::AIDFAM704>3.0.CO;2-J

Creswell, J. W. (2013). Qualitative Inquiry and Research Design: Choosing Among Five Approaches (Third Edition). SAGE.

Fahrevy, Sari, S. A., \& Indra. (2014). Kajian Tingkat Pengetahuan Kepala Keluarga Dalam Menghadapi Bencana Gempa Bumi Di Kecamatan Baitussalam Kabupaten Aceh Besar. 
Cakradonya Dental Journal, 6(2), 737-744.

http://www.jurnal.unsyiah.ac.id/

CDJ/article/view/10430

Firmansyah, I. (2014). Hubungan pengetahuan dengan perilaku kesiapsiagaan dalam menghadapi bencana banjir dan longsor pada remaja usia 15-18 tahun di sma alhasan kemiri kecamatan panti kabupaten jember. http://repository.unej.ac.id/handl e/123456789/56880

Fujisaki. (1979). Miyagi-ken-oki Earthquake and Medical System. Newsletter of Miyagi Medical Association, 446-456.

Goto, Y. (2011). Fact-finding about evacuation from the unexpectedly large tsunami. Proc. of One Year After.

Haryadi. (2010). Arsitektur, lingkungan, dan perilaku: Pengantar ke teori, metodologi, dan aplikasi. Gadjah mada University Press.

Huo, F. Z., Song, W. G., Liu, X. D., Jiang, Z. G., \& Liew, K. M. (2014). Investigation of Human Behavior in Emergent Evacuation from an Underground Retail Store. Procedia Engineering, 71 , 350-356. https://doi.org/10.1016/j.proeng. 2014.04.050

Kumar, R. (2018). Research Methodology: A Step-by-Step Guide for Beginners. SAGE.

Kurniawati, D., \& Suwito, S. (2017). PENGARUH PENGETAHUAN KEBENCANAAN TERHADAP SIKAP KESIAPSIAGAAN DALAM MENGHADAPI BENCANA PADA MAHASISWA PROGRAM STUDI PENDIDIKAN GEOGRAFI UNIVERSITAS KANJURUHAN MALANG. JPIG (Jurnal Pendidikan Dan Ilmu Geografi), 2(2), Article 2. https://doi.org/10.21067/jpig.v2i 2.3507

Murakami, H. O., \& Durkin, M. E. (1988). Studies of occupant behavior in earthquakes review and perspectives. STUDIES, 13, 3-1. http://www.iitk.ac.in/nicee/wcee /article/9_vol7_681.pdf

Odani, M., \& Uranaka, K. (1999). Road block in area affected by the great Hanshin-Awaji earthquake and influence of blockage on traffic flow. Journal of the Eastern Asia Society for Transportation Studies, 3(6), 151-164.

Ohta, Y., \& Ohashi, H. (1985). Field Survey on Occupant Behavior in an Earthquake. International Journal of Mass Emergencies and Disasters, 3(1), 147-160. https://www.safetylit.org/citatio ns/index.php?fuseaction=citation s.viewdetails\&citationIds[]=citjou rnalarticle_56018_35

Okabe, K., \& Hirose, H. (1985). The General Trend of Sociobehavioral Disaster Studies in Japan. International Journal of Mass Emergencies and Disasters, 3(1), 7-19. https://www.safetylit.org/citatio ns/index.php?fuseaction=citation s.viewdetails\&citationIds[]=citjou rnalarticle_56019_38

Rapoport, A. (2016). Human Aspects of Urban Form: Towards a ManEnvironment Approach to Urban Form and Design. Elsevier.

Sagun, A., Anumba, C. J., \& Bouchlaghem, D. (2013). Designing Buildings to Cope with Emergencies: Findings from Case Studies on Exit Preferences. Buildings, 3(2), 442461.

https://doi.org/10.3390/building s3020442

Song, X., Zhang, Q., Sekimoto, Y., \& Shibasaki, R. (2014). Prediction of human emergency behavior and their mobility following large-scale disaster. Proceedings of the 20th ACM SIGKDD International Conference on Knowledge Discovery and Data Mining, 5-14. https://doi.org/10.1145/262333 0.2623628

Ursano, R. J., McCaughey, B. G., \& Fullerton, C. S. (1995). Individual and 
Community Responses to Trauma and Disaster: The Structure of Human Chaos. Cambridge University Press.

Yun, N.-Y., \& Hamada, M. (2012). Evacuation behaviors in the 2011 Great East Japan earthquake. Journal of Disaster Research, 7(7), 458-467.

\section{Kontribusi penulis}

Ulfa Mazaya berkontribusi pada persiapan konsep penelitian, metodologi, investigasi, analisis data, visualisasi. penyusunan artikel dan revisi.

Marlisa Rahmi berkontribusi pada penyusunan konsep penelitian dan tinjauan pustaka, analisis data, penyusunan dan validasi draf artikel

Hanson E. Kusuma berkontribusi pada penyusunan konsep penelitian dan tinjauan pustaka, analisis data, penyusunan dan validasi draf artikel 